\title{
Open hole size effects on tensile properties of 3D braided composites
}

DOI: 10.35530/IT.072.05.202010

\section{ABSTRACT - REZUMAT \\ Open hole size effects on tensile properties of 3D braided composites}

Owing to the excellent integrated structure, notch-insensitivity, delamination-free characteristics, 3D braided composites have a broad range of engineering applications. In this paper, the notch size effects on two types of $3 D$ braided composites were experimentally examined. Style I incorporated $40 \%$ of longitudinal lay-in yarns. Style II was the pure braids. The Point Stress Criterion (PSC) was applied to predict the open-hole strength of 3D braided composites. It is found the $3 D$ braided composites can keep higher proportion residual strength after involving the different circular hole sizes compared to plain woven laminates. The open-hole pure braided specimen shows better performance than that the braids with longitudinal yarns, the lay-in longitudinal yarns improve neither specimens' un-notched strength, nor the modulus. The predicted open-hole strength were compared with experimental results. The traditional analytical method can predict the open-hole strength of $3 D$ braided composite to some extent. Under uniaxial tensile stress, the failure behaviour of two types of 3D braided specimens are different. For un-notched specimen, clear cracks usually show up on the Style II specimen, while it is not true for Style I coupon. For notched specimen, the crack of both notched specimens will propagate along the notch and finally render the specimen to fail.

Keywords: 3D braided composite, open-hole size, Point Stress Criterion, failure, strength prediction

\section{Influența dimensiunilor orificiilor asupra proprietăților de tracțiune ale compozitelor împletite 3D}

Datorită structurii integrate excelente, insensibilității canelurilor, caracteristicilor fără exfoliere, compozitele împletite $3 D$ au o gamă largă de aplicații inginerești. In această lucrare, efectele dimensiunii canelurilor au fost examinate experimental pe două tipuri de compozite împletite 3D. Tipul I a inclus $40 \%$ din firele de umplutură longitudinale. Tipul Il a fost reprezentat de împletiturile propriu-zise. Point Stress Criterion (PSC) a fost aplicat pentru a preconiza rezistența orificiului deschis al compozitelor împletite 3D. Se constată că, compozitele împletite $3 D$ pot păstra o rezistență reziduală proporțională mai mare după implicarea diferitelor dimensiuni ale orificiilor circulare în comparație cu țesăturile simple laminate. Proba împletită propriu-zisă cu orificii deschise prezintă performanțe mai bune decât cea împletită cu fire longitudinale, firele longitudinale de umplutură nu îmbunătățesc nici rezistența probelor și nici modulul. Rezistența preconizată a orificiilor deschise a fost comparată cu rezultatele experimentale. Metoda analitică tradițională poate preconiza într-o oarecare măsură rezistența orificiului deschis al compozitului împletit 3D. În condiții de tensiune uniaxială, comportamentul la deteriorare al celor două tipuri de probe împletite $3 D$ este diferit. Pentru proba fără caneluri, fisurile clare apar de obicei pe proba tip II, dar nu apar pe proba tip I. Pentru proba cu caneluri, fisura ambelor probe se va propaga de-a lungul canelurii și, în cele din urmă, va duce la deteriorarea probei.

Cuvinte-cheie: compozit împletit 3D, dimensiunea orificiului deschis, Criteriul de stres punctual, deteriorare, preconizarea rezistenței

\section{INTRODUCTION}

Braided composites have gained considerable attention over the past years in a variety of applications, e.g. airframe spars, fuselage frames, rocket nose cones, ship propeller blades, engine nozzles, biomedical devices, etc. [1-3]. Compared to conventional unidirectional and woven laminate composites, the sustained interest in 3D braided composites can be attributed to the proven damage tolerance [4], delamination-free characteristics, and an ability to create net complex shape structures in a digitally controlled manner [5]. One of the most earlier studies of the structural properties of 3D braided composites was carried out by Gause and Alper [6]. In their study they evaluated a wide range of the static and dynamic mechanical properties of 3D braided composites including open hole static strength and tensile fatigue behaviour, they demonstrated that the 3D braided composites are notch (open hole) insensitive. Du and Ko [7] first examined 3-D braiding methods in the light of braid structures, followed by the development of geometric models for 3D braids using a unit cell approach. Portanova et al. [8, 9] examined the fatigue properties of un-notched 3D braided composites, it was found the residual fatigue life of $3 \mathrm{D}$ braided composite was sufficient to satisfy current composite damage tolerance design criteria.

One of the key considerations in the design of composite aircraft structures is the ability of the composite 
to tolerate damage created during manufacturing, like drilling holes. It is an important issue for composite structure design to predict the open hole strength accurately. Lot of studies have been done on openhole effects on laminated composite. Whitney and Nuismer [10,11] proposed approximate solution to calculate the normal stress distribution adjacent to a circular hole in an infinite orthotropic plate was present in the form of polynomial. Norman and Anglin studied how open hole affects failure in 2D braided textile composite materials under tensile loading. They found un-notched tape equivalents are stronger than braided textiles but exhibited greater notch sensitivity. Notch strength could not be predicted using existing anisotropic theory for braided textiles. Damage initiation stress decreases with increasing braid angle [12]. Hwan and Tsai [13] studied the notched strengths of three kinds of braided composite plates with a centre hole, also point stress criterion (PSC) and average stress criterion (ASC) were applied to predict the strength of $2 \mathrm{D}$ braided composite plate with different sizes of the hole. Kohlman and Bail gave a notched coupon geometry method for tensile testing of 2D triaxial braid composites, which they claim the notch specimen is easier to fabricate [14].

Although many references with regard to hole size effects on laminates and notched strength prediction of laminated composites have been found and briefly introduced above, up to now, limited studies are available in the literature to study the effects of notch size on 3D braided composites. Accordingly, the objective of this study is to experimentally study the open hole sizes effects on 3D braided composites. The traditional analytical PSC criterion was also used to predict the open-hole strength of 3D braided composites

\section{EXPERIMENTAL AND THEORETICAL METHODS \\ Material}

HEXCEL AS4 6K carbon yarns are used as reinforced material, an epoxy system consisting of West System 105 resin and 209 curing agent (mix ratio = 3.68:1 by weight) was used as matrix material. According to the manufacturing datasheet, the properties of matrix and yarns are shown in table 1.

\begin{tabular}{|c|c|c|}
\hline \multicolumn{2}{c}{ Table 1} \\
\hline \multicolumn{2}{|c|}{ PROPERTIES OF MATRIX AND CARBON FIBRE } \\
\hline Properties & Matrix & AS4-6k \\
\hline Tensile modulus $(\mathrm{GPa})$ & 2.74 & 231 \\
\hline Tensile strength $(\mathrm{MPa})$ & 51 & 4447 \\
\hline Strain $(\%)$ & 3.6 & 1.7 \\
\hline Density $\left(\mathrm{g} / \mathrm{m}^{3}\right)$ & 1.16 & 1.78 \\
\hline
\end{tabular}

3D braided preforms were produced on a Cartesian four-step 3D braider. Two types of the braided preforms were fabricated. Style I incorporated $42 \%$ of longitudinal lay-in yarns (totally 129 yarns). Style II was the basic $(1 \times 1)$ pattern, with 124 yarns. The 3D braided preforms have a surface braiding angle of $\pm 20^{\circ}$, and the actual cured braided specimen orientation is approximately $\pm 18^{\circ}$, because of the compression in the closed mould during the curing process. The information of fabrics used in this paper are shown in table 2.

The dry preform was infused resin by RTM technology, a compressive mould was design for the sample manufacturing. Then, the fully cured composite in the shape of rectangular bar having $25.4 \mathrm{~mm}$ width was released from the mould. The volume fraction of the specimen was determined by measuring the density the coupon. For un-notched samples, the experimentally measured fibre volume fraction was $58 \%$ for Style I and $60 \%$ for Style II coupons.

Table 2

\begin{tabular}{|c|c|c|c|c|}
\hline \multicolumn{5}{|c|}{ FABRICS USED AS REINFORCED IN THE 3D } \\
BRAIDED COMPOSITE \\
\hline $\begin{array}{c}\text { Fabric } \\
\text { structure }\end{array}$ & $\begin{array}{c}\text { No. of } \\
\text { layers }\end{array}$ & $\begin{array}{c}\text { No. of } \\
\text { yarns }\end{array}$ & $\begin{array}{c}\text { Dimension } \\
\text { (mm) }\end{array}$ & $\begin{array}{c}\text { Braiding } \\
\text { angle } \\
(\mathbf{0})\end{array}$ \\
\hline Style I & 4 & 129 & $\begin{array}{c}25.4 \text { by } 3 \pm \\
0.1 \text { by } 250\end{array}$ & $\pm 20 \pm 1$ \\
\hline Style II & 5 & 124 & $\begin{array}{c}25.4 \text { by } 2.9 \pm \\
0.1 \text { by } 250\end{array}$ & $\pm 20 \pm 1$ \\
\hline
\end{tabular}

The 3D braided composite are sensitive to the edge cutting for the cutting along the braiding direction will break the integrated characteristic of 3D braided specimen [15]. So all the preforms are fabricated with width closed to $25.4 \mathrm{~mm}$, and thus avoid cutting from big panel. The different series of holes were drilled at the centre of the specimen using special CBN diamond core drill bits. The dimension of un-notched specimen is same with the notched one. For small hole sample preparation, the tab were bonded to the end of the coupon to avoid the sample break inside the clamps when do the test. While it is no need to bond the ta for large circular hole size specimen, it is already involved large stress concentration. The unit cells for Style I and Style II specimen are shown in figure 1. Photographs of cross-sectional areas of Style I 3D braided specimen were shown in figure 2 .

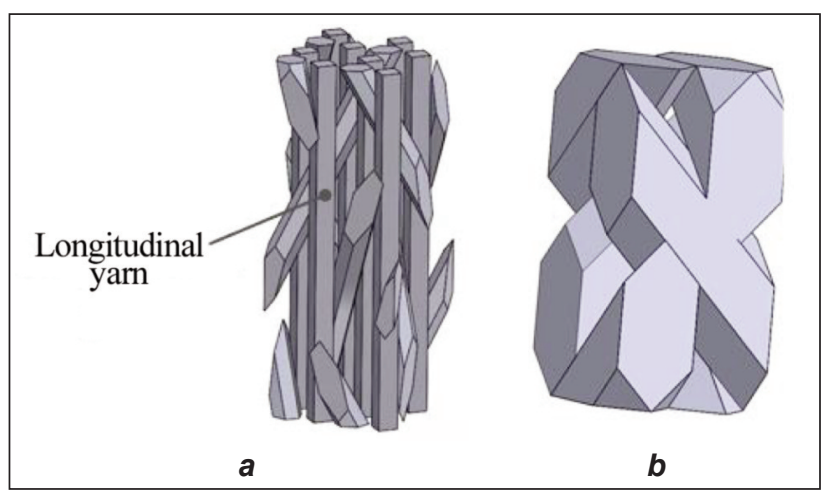

Fig. 1. Unit cell of 3D braided specimens: $a$ - Style I; $b$ - Style II 


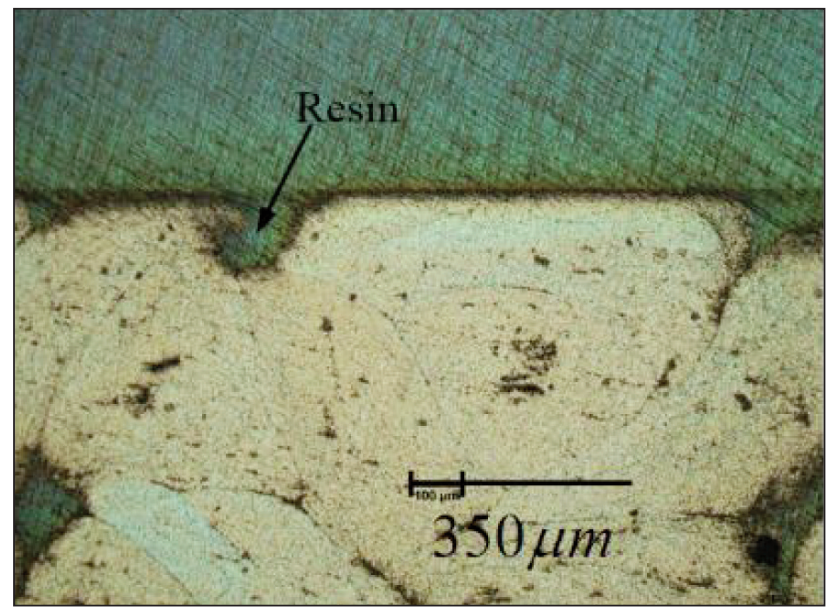

a

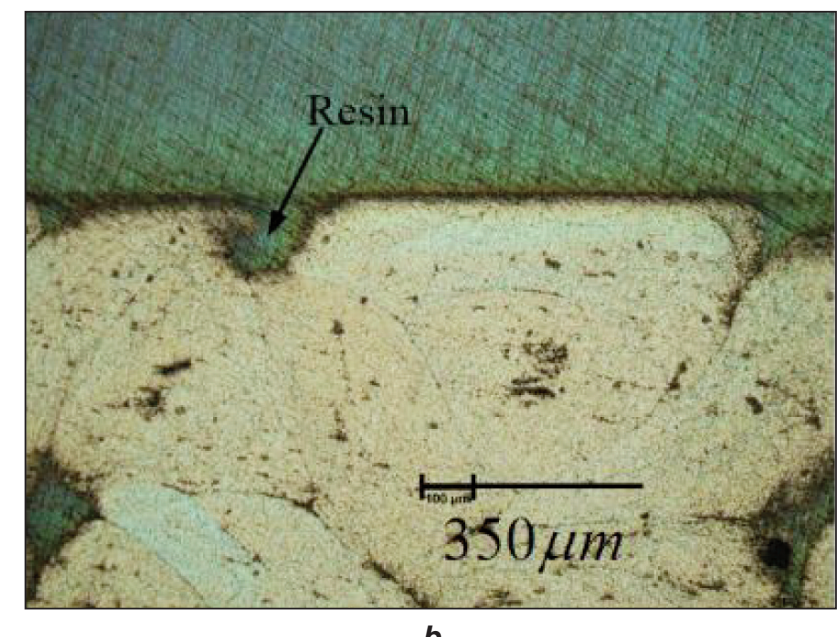

$\boldsymbol{b}$

Fig. 2. Photographs of cross-sectional areas of 3-D braided composite: $a$ - Style I; $b$ - Style II

The yarn cross section of pure braids is usually more uniform than Style I with axial yarns. The Style I has more resin rich area in the interlacing area than Style II, resin rich areas usually appear on yarn interlacing area.

\section{Testing method}

The static un-notched tensile strength and notched are conducted according to the ASTM D3039 and ASTM D5766, respectively. For each group tests, 5 samples were tested to obtain the mean tensile strength, with cross-head moving rate of $2 \mathrm{~mm} / \mathrm{min}$. All the specimens were tested on a MTS servohydraulic mechanical testing unit under constant displacement rate of $2 \mathrm{~mm} / \mathrm{min}$. The test equipment and painted specimen were shown in figure 3.

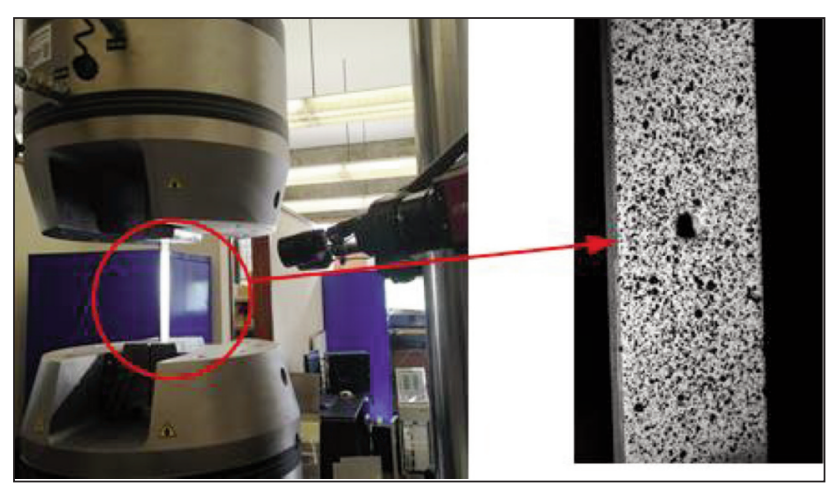

Fig. 3. The testing equipment

\section{Notched specimen strength prediction}

The 3D braided plate can be taken as orthotropic material. The notched tensile strength of the 3D braided composite were predicted following Point Stress Criterion (PSC) proposed by Whitney et al. $[10,11,16]$, based on the stress distribution adjacent to the notch. In this criterion, failure is assumed to occur when the stress $\sigma_{y}$ at some fixed distance $\left(d_{0}\right)$ ahead of the notch becomes equal to the un-notched strength $\left(\sigma_{0}\right)$ of the material. For a circular hole, the failure occurs according to the following equations:

$$
\left.\sigma_{y}(x, 0)\right|_{x=R+d_{0}}=\sigma_{0}
$$

For an infinite orthotropic plate containing a circular hole of radius $R$ and subjected to uniform stress $\sigma$ applied parallel to the $y$-axis at infinity, the normal stress $\left(\sigma_{y}\right)$ along to the $x$-axis ahead of the hole can be expressed approximately by:

$$
\begin{gathered}
\sigma_{y}(x, 0)=\frac{\sigma}{2}\left[2+\left(\frac{R}{x}\right)^{2}+3\left(\frac{R}{x}\right)^{4}-\left(K_{T}-3\right) 5\left(\frac{R}{x}\right)^{6}-\right. \\
\left.-7\left(\frac{R}{x}\right)^{8}\right], \quad x>R
\end{gathered}
$$

where $K_{T}$ is the stress concentration factor for an infinite orthotropic plate [17]. The notched strength of an infinite width plate can be predicted by:

$$
\sigma_{N}=2 \sigma_{U} /\left[2+A^{2}+3 A^{4}-\left(K_{T}-3\right)\left(5 A^{6}-7 A^{8}\right)\right]
$$

where $\sigma_{N}, \sigma_{U}$ is the notched strength and un-notched tensile strength of the plate, respectively. The characteristic lengths $d_{0}=1$ were chosen, as suggested by Nuismer et al. [16]:

$$
A=R /\left(R+d_{0}\right)
$$

\section{RESULTS}

This section presents results of the un-notched and notched tensile test of the specimens, also the comparison with the published 3D braided composite and laminates. The failure behaviour of notched and notched coupons of 3D braided composites were also observed.

\section{Comparison with laminates}

Figure 4 shows the stress-strain curve of the two types of un-notched samples up to failure, the stressstrain curve measured by DIC. The two types of braids show close strength and modulus, the adding axial yarn improve neither the modulus nor the strength. It is due to the adding yarn affect and volume fraction difference of the specimen. The natural behaviour of the lay-in yarn along the braiding direction in the preform is straight, whereas after the sample 


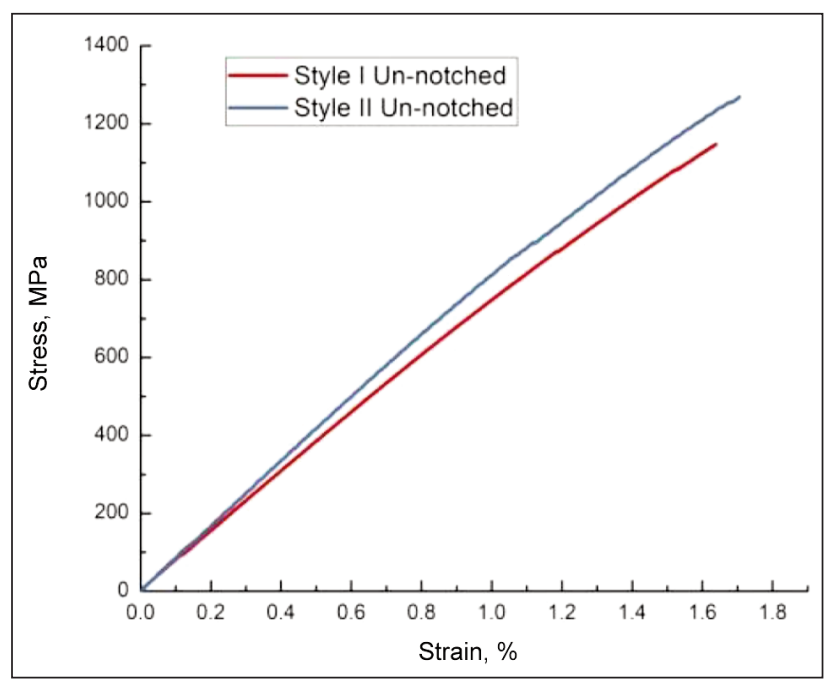

Fig. 4. Un-notched 3D braided composite quasi-static tension tests: stress vs. strain curves

cured in the compressive mould, the adding axial yarn may not straight, which should be observed using CT regeneration technology in the future. Also the adding in-lay yarn decreases the volume fraction of the coupon, as shown in figure 2. The DIC strain field of Style II sample with $5 \mathrm{~mm}$ hole at $50 \mathrm{KN}$ was shown in figure 5 . Figure 5 presents the shear strain $\varepsilon_{x y}$, longitudinal (loading direction) strain distribution $\varepsilon_{y y}$ and transverse strain distribution $\varepsilon_{x x}$, respectively. It is found the existence of hole affect the strain distribution near the hole.

Figure 6 shows the comparison of measured mechanical properties of the un-notched 3D braided composite and notched with a hole of $5 \mathrm{~mm}$ and published results on 3D braided composite and lamination composites with plied angle $\left( \pm 20^{\circ}\right)$. The four columns on left hand represent the $3 \mathrm{D}$ braided specimen; the right hand corresponds to laminates. It is found the tensile strength of the entire notched 3D braided composite is higher than that of laminated composites. It found the 3D braided composite at low braiding angle can contain damage better than laminates with similar plied angle. The 18-ply $\left(0 \pm 20^{\circ}\right)$ laminates [18] have the similar tensile strength with present results, after drilling the hole, the laminates can only keep $58 \%$ of the tensile strength, while the present both 3D braided composites can keep $74-79 \%$ of the tensile strength. This confirms that the 3D braided composites are less notch sensitive than laminated composites [4, 6]. The present two types of 3D braided specimen with or without longitudinal yarns shows similar modulus and failure strength under low braiding angle.

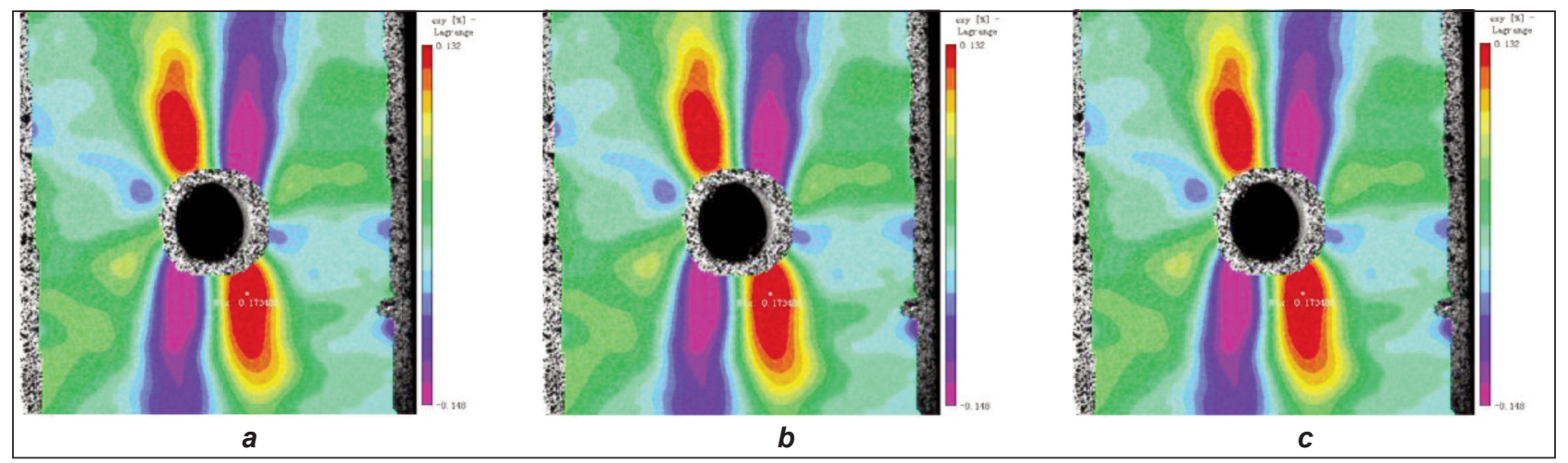

Fig. 5. DIC strain filed at $50 \mathrm{KN}$ for Style II notched 3D braided specimen: $a-\varepsilon_{x y} ; b-\varepsilon_{y y} ; c-\varepsilon_{x x}$

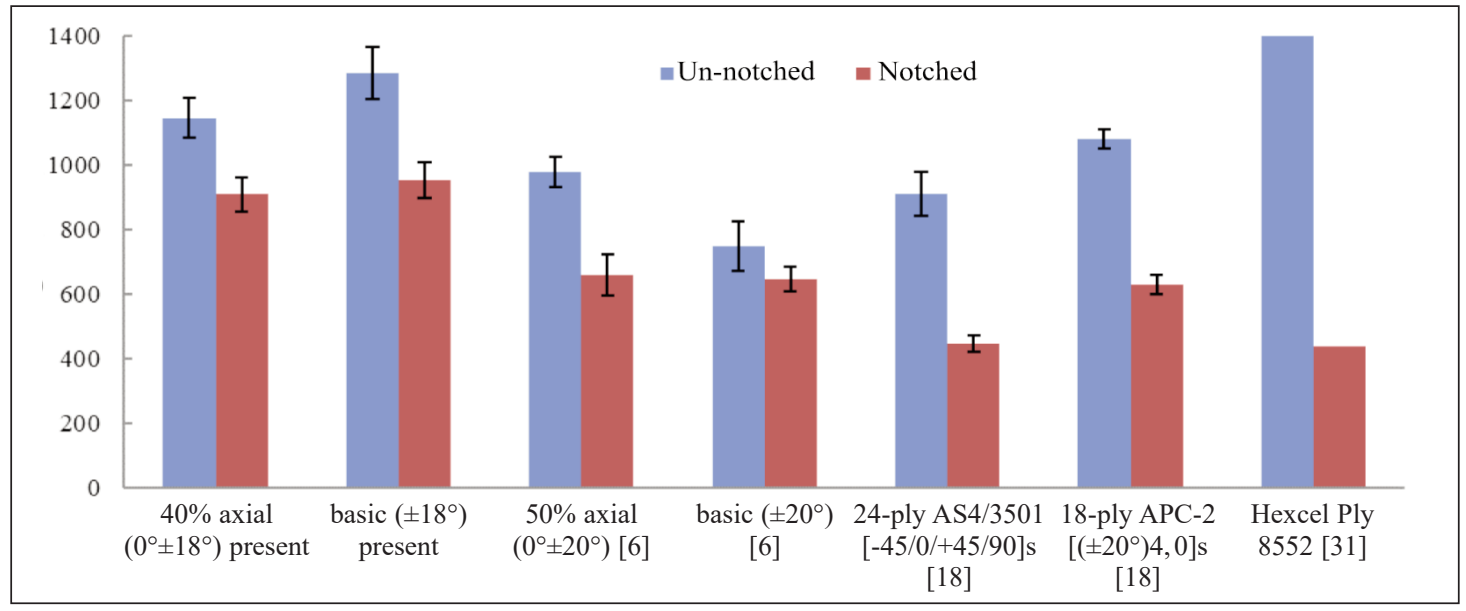

Fig. 6. Mechanical properties of the 3D braided composite and laminates 
Typical tensile load versus displacement curve of Style I and Style II 3D braided specimen are shown in figure 7. Although involving different hole size, the both braids still show similar slope, as talked before, the two types of braided composite have similar modulus and strength. The different series of hole sizes affect the failure strength and failure elongation significantly. As expected, the sample failed earlier when involved large size open circular hole. Table 3 summarized the tension strength with different hole size of 3D notched and unnotched braided composite. Each result was from five different specimens for $3 D$ braided composite. $\sigma_{N}$ is notched strength, $\sigma_{U}$ is unnotched strength. The experimental results presented in table 3 clearly identify the size effects on 3D braided composites: an increase of the hole diameter from $2.8-11.2 \mathrm{~mm}$ result in a reduction in the strength of $44 \%$.

The results were compared to plain woven laminates $\left(V_{f}=60 \%\right)$ [19], the both types of 3D braids show better performance. The laminates can only keep $32 \%$ of the un-notched strength when the hole diameter to width ratio is 0.5 , while the both $3 \mathrm{D}$ braids can keep more than $46 \%$ of the original strength [19]. The final strength of 3D braided composites is also much higher than plain woven laminates. For woven laminates, the final open-hole strength is only $321 \mathrm{MPa}$, while the braids can retain more than $500 \mathrm{MPa}$ of the strength.

The predicted notched value and comparison with experimental results are presented in figure $8, a$. The hole size effects on different fibre architecture in the 3D braided composite are different. The pure braided composite can retain higher proportion of the notched strength than the specimen with axial yarn, with all series of circular hole size. The 3D braided compos-

\begin{tabular}{|c|c|c|c|c|c|}
\hline \multicolumn{5}{|c|}{ STRENGTH OF 3D NOTCHED AND UN-NOTCHED COM- } \\
\hline \multirow{3}{*}{$\mathbf{W}(\mathbf{m m})$} & $\mathbf{2 R / \mathbf { W }}$ & $\begin{array}{c}\mathbf{2 R} \\
(\mathbf{m m})\end{array}$ & $\sigma_{N} / \mathrm{MPa}$ & $\begin{array}{c}\text { STDV } \\
\mathbf{( M P a})\end{array}$ & $\sigma_{N} / \sigma_{U}$ \\
\hline \multirow{4}{*}{$\begin{array}{c}\text { Style I } \\
\sigma_{U}=1147 \mathrm{MPa} \\
E_{X}=70.5 \mathrm{GPa}\end{array}$} & 0.12 & 2.8 & 1006 & 68 & 0.87 \\
\cline { 2 - 6 } & 0.19 & 5 & 900 & 57 & 0.78 \\
\cline { 2 - 6 } & 0.31 & 7.85 & 670 & 49 & 0.58 \\
\cline { 2 - 6 } & 0.39 & 9.74 & 573 & 42 & 0.49 \\
\hline \multirow{4}{*}{$\begin{array}{c}\text { Style II } \\
\sigma_{U}=1287 \mathrm{MPa} \\
E_{X}=75.2 \mathrm{GPa}\end{array}$} & 0.45 & 11.2 & 500 & 43 & 0.46 \\
\cline { 2 - 6 } & 0.12 & 2.8 & 1100 & 60 & 0.87 \\
\cline { 2 - 6 } & 0.31 & 7.85 & 786 & 52 & 0.62 \\
\cline { 2 - 6 } & 0.39 & 9.74 & 674 & 45 & 0.53 \\
\hline \multirow{3}{*}{$\begin{array}{c}\text { Laminates }[19] \\
\sigma_{U}=581.2 \mathrm{MPa}\end{array}$} & 0.45 & 11.2 & 582 & 48 & 0.47 \\
\cline { 2 - 6 } & 0.10 & 2.0 & 454.0 & - & 0.773 \\
\cline { 2 - 6 } & 0.40 & 4.0 & 388.8 & - & 0.639 \\
\cline { 2 - 6 } & 0.50 & 10.0 & 321.8 & - & 0.318 \\
\hline
\end{tabular}

ite having longitudinal yarns are sensitive to hole size, compared to pure braids. For un-notched strength prediction, the FGM were followed. It was found the predicted un-notched strength is quite close to the experimental value. For notched strength prediction, when the characteristic lengths $d_{0}$ is 1 [16], the traditional analytical method can predict the reduction trend of notched strength of $3 \mathrm{D}$ braided composite to some extent. However, to predict the open-hole strength of 3D braided composites accurately, the model needs to be modified and improved, more work need to done on this method.

The relation between the normalized notched strength and the ratio between the hole diameter is

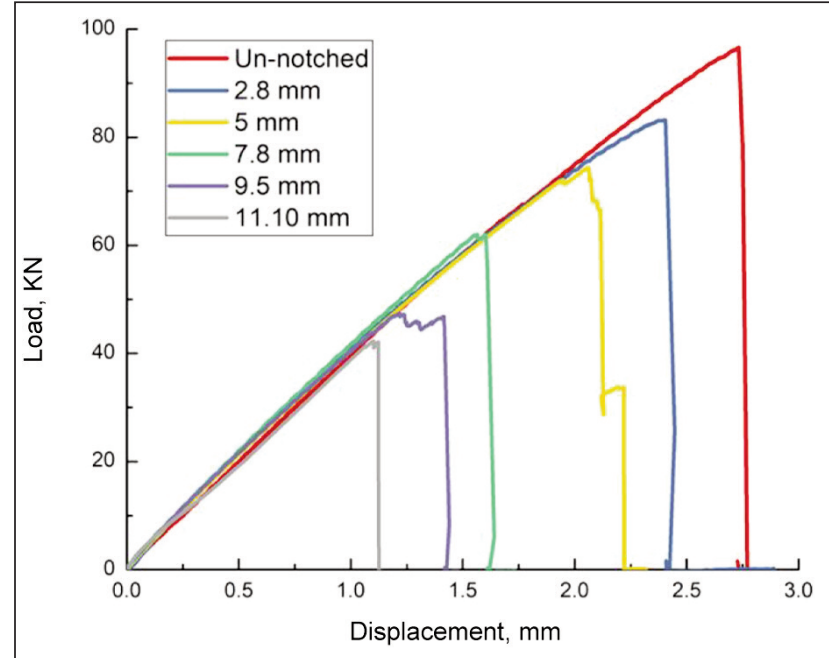

a

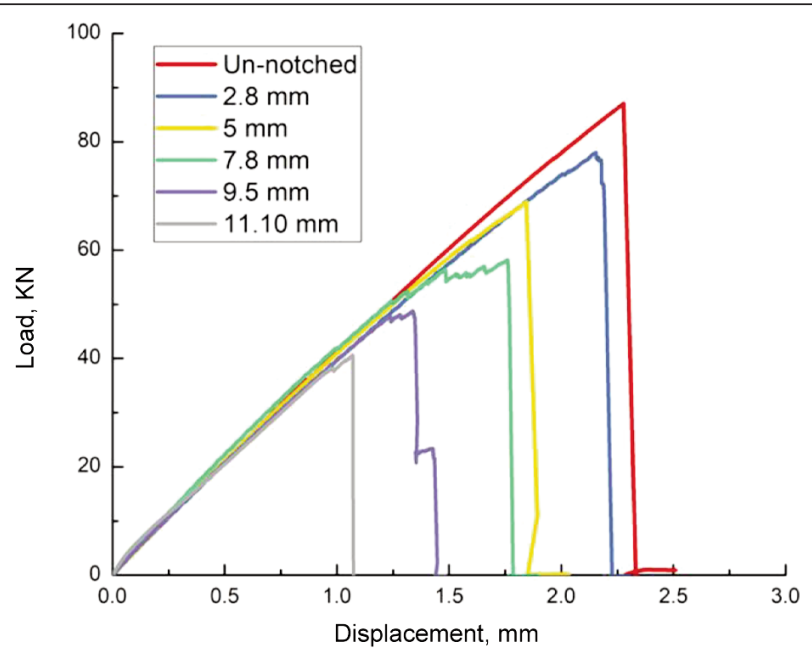

b

Fig. 7. Notched specimen Load vs Displacement curves: $a$ - Style I; $b$ - Style II 


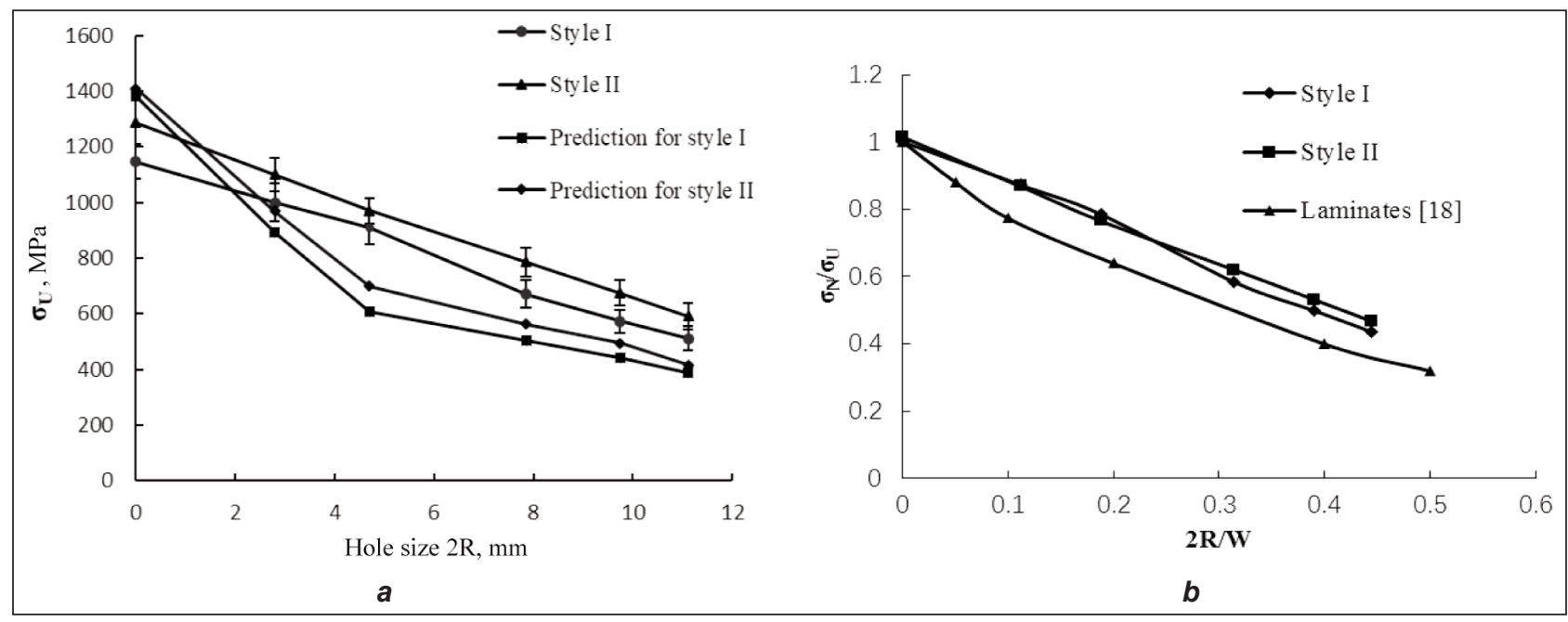

Fig. 8. Comparison of: $a$ - the experimental and predicted notched strength of 3D braided composites; $b$ - normalized notched strength versus hole size to width ratio

shown in figure $8, b$. Also the data from paper was present to do the comparison with the $3 \mathrm{D}$ braided composite. As the open-hole size increases, the both braids lose strength in similar trend, the final notched strength of Style I is still lower than basic pattern. Compared to woven laminates, the both two types of 3D braided composites show better performance and higher notched strength than laminates. The 3D braids are less insensitive to the circular hole size compared to woven laminates.

\section{Failure behaviour}

In this part, the failure behaviour of un-notched and notched specimens of 3D braided composites are presented. Figure 9 show the photographs of unnotched specimens for Style I and Style II after the tension test, respectively. The two types of unnotched 3D braided coupons perform different failure behaviour, fibre architecture in the 3D braided composite was found to play a significant role in the damage resistance of the composite. The pure braids tend to show clear cracks, while it is not true for the samples with longitudinal yarn, as shown in figure 9. It is mainly because the damage propagates the axial

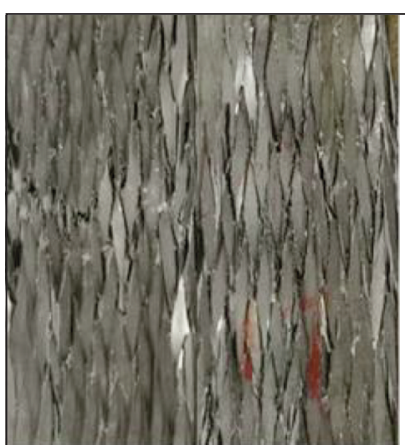

a

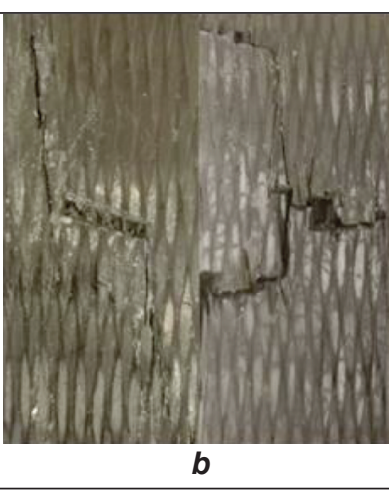

Fig. 9. Photographs of un-notched 3D braided specimens after the tensile tests: $a-$ Style I; $b$ - Style II

yarn direction. Figure 10 show the picture of the specimens with different hole size for Style I and Style II after tensile test. Compared with un-notched failure shape, the both notched specimen show consistent failure shape, failure always originated from the hole edge and along the braiding angle direction, finally rendering failure of the specimen, whereas clear crack still show up on pure braided coupons, but not for samples with axial yarn.
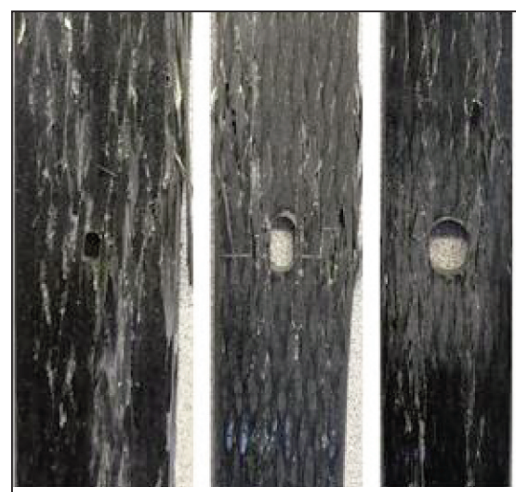

a
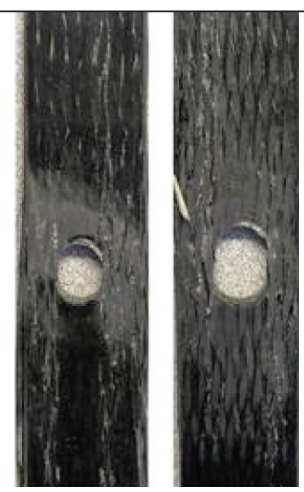
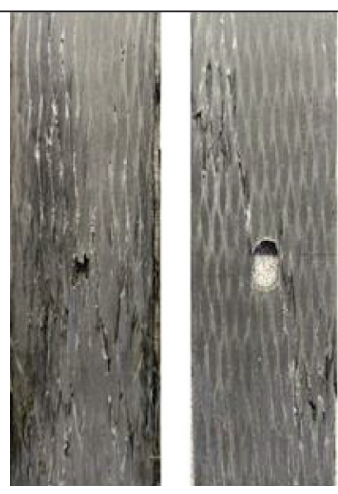
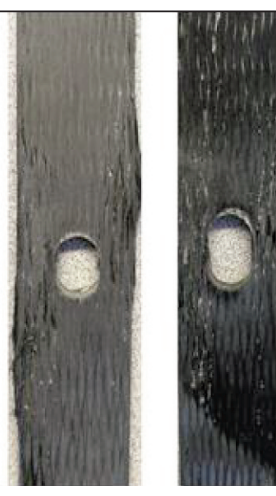

b

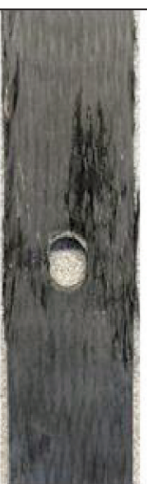

Fig. 10. Photographs of notched 3D braided specimens with different hole size after the tensile tests: $a$ - Style I; $b$ - Style II 


\section{CONCLUSIONS}

In this paper, the notch size effects on two types of 3D braided composites were experimentally examined, the results were compared to plain woven laminated composites. It is found the 3D braided composites can keep higher proportion residual strength under tension loading after involving different series of open hole compared to laminates with same plied angle. The open-hole pure braids show better performance than that the braids with longitudinal yarns, the lay-in longitudinal yarns improve neither specimens' un-notched strength, nor the modulus. Considering the time consuming for the complex preform with axial yarn, the pure braids will be the right option for 3D braided structure design. The PSC criterion was applied to predict the open-hole strength of 3D braided composite, the predicted value were compared with experimental results. The traditional analytical method can predict the open-hole residual strength of 3D braided composite to some extent, more study should be done on this work in the future.

\section{ACKNOWLEDGEMENTS}

The authors would like to acknowledge the financial support from National Key R\&D Program of China under the project 2016 YFB0303300.

\title{
REFERENCES
}

[1] Mouritz, A., Bannister, M., Falzon, P., Leong, K., Review of applications for advanced three-dimensional fibre textile composites, In: Composites Part A: Applied Science and Manufacturing, 1999, 30, 12, 1445-1461

[2] Shivakumar, K., Cozart, A., Analysis of 3-D braided composite ablative rocket nozzle, In: ASME 2002 Joint US-European Fluids Engineering Division Conference, American Society of Mechanical Engineers, 2002

[3] Bilisik, K., Three-dimensional braiding for composites: A review, In: Textile Research Journal, 2013, 83, 13, 1414-1436

[4] Dow, M., Dexter H., Development of stitched, braided and woven composite structures in the ACT program and at Langley Research Center, 1997

[5] Ko, F.K., Three-dimensional fabrics for composites, In: Textile Structural Composites, Elsevier Science Publishers, 1989, 129-171

[6] Gause, L., Alper, J., Structural properties of braided graphite/epoxy composites, In: Journal of Composites, Technology and Research, 1987, 9, 4, 141-150

[7] Du, G., Ko, F.K., Unit cell geometry of 3-D braided structures, In: Journal of Reinforced Plastics and Composites, 1993, 12, 7, 752-768

[8] Portanova, M., Fatigue resistance of unnotched and post impact (+/-30 deg/0 deg) 3-D braided composites, 1994

[9] Carvelli, V., Pazmino, J., Lomov, S., Quasi-static and fatigue tensile behavior of a 3D rotary braided carbon/epoxy composite, In: Journal of Composite Materials, 2012, 47, 25, 3195-3209

[10] Whitney, J., Nuismer, R., Stress fracture criteria for laminated composites containing stress concentrations, In: Journal of composite materials, 1974, 8, 3, 253-265

[11] Konish, H., Whitney, J., Approximate stresses in an orthotropic plate containing a circular hole, In: Journal of Composite Materials, 1975, 9, 2, 157-166

[12] Norman, T.L., Anglin, C., Gaskin, D., Patrick, M., Effect of open hole on tensile failure properties of 2D triaxial braided textile composites and tape equivalents, 1995

[13] Hwan, C.L., Strength prediction of braided composite plates with a center hole, In: Journal of Composite Materials, 2011, 45, 19, 1991-2002

[14] Kohlman, L., Bail, J., Roberts, G., Salem, J., Martin, R., Binienda, W., A notched coupon approach for tensile testing of braided composites, In: Composites Part A: Applied Science and Manufacturing, 2012, 43, 10, 1680-1688

[15] Macander, A.B., Crane, R.M., Camponeschi, E.T., Fabrication and mechanical properties of multidimensionally (XD) braided composite materials, In: Composite Materials: Testing and Design (Seventh Conference), ASTM International, 1986

[16] Nuismer, R., Whitney, J.M., Uniaxial failure of composite laminates containing stress concentrations, In: Fracture mechanics of composites, ASTM International, 1975

[17] Tan, S.C., Stress concentrations in laminated composites, 1994

[18] Hua, C.T., Chu, J.N., Ko, F.K., Damage tolerance of three-dimensional commingled PEEK/carbon composites, In: Composite Materials: Testing and Design (Tenth Volume), ASTM International, 1992

[19] Kim, J.K., Kim, D.S., Takeda, N., Notched strength and fracture criterion in fabric composite plates containing a circular hole, In: Journal of composite materials, 1995, 29, 7, 982-998

\section{Authors: \\ SHUANGQIANG LIANG, QIHONG ZHOU, GE CHEN}

Donghua University, Department of Mechanical Engineering, Postal address, 201620, Shanghai, China

\section{Corresponding authors:}

\author{
SHUANGQIANG LIANG \\ e-mail: Isq66122662@163.com \\ GE CHEN \\ e-mail: chenge@dhu.edu.cn
}

